\title{
Model and Strategy Acceleration of Rural Poverty Alleviation
}

\author{
A Study in Jambi Province
}

\author{
Syaparuddin, \\ Economic Faculty of Universitas Jambi, Jambi-Indonesia \\ syaparuddinunja@gmail.com \\ Siti Hodijah \\ Economic Faculty of Universitas Jambi, Jambi-Indonesia \\ DOI: 10.31364/SCIRJ/v7.i6.2019.P0619662 \\ http://dx.doi.org/10.31364/SCIRJ/v7.i6.2019.P0619662
}

\begin{abstract}
Poverty is a very interesting phenomenon and has always been an issue that is always debated in the midst of society, technocratic or academic. This study aims to (1) Identify the description of the rural poverty of Jambi Province, (2) Formulate a model for accelerating rural poverty reduction in Jambi Province and (3) Designing strategy for accelerating rural poverty reduction in Jambi Province. The data analysis techniques used in combining qualitative and quantitative descriptive methods. The results showed that the number and percentage of poor people, most of the districts in Jambi Province tended to increase in 2017 compared to 2010. The districts were Merangin, Batang Hari, TanjungJabungTimur, TanjungJabung Barat, Bungo and Tebo. The model of accelerating rural poverty alleviation in Jambi Province which can be
\end{abstract}

\section{INTRODUCTION}

Poverty (Poverty reduction) is an issue that has always been debated for more than two decades. The poverty alleviation program is the main measure of the success of development policies, especially in the 1970s until the 1980s. Poverty is a long-term problem [1]. Various views and opinions of economists, especially Development Economics experts who see that the reduction in poverty is a central goal for the development of a country that can be achieved through economic growth or income distribution. Almost all countries, especially developing countries, have raised the issue as the main development policy in the era of the 1990s [2].

The failure or lack of success of poverty alleviation does not only occur in Indonesia, but in many countries, especially in developing countries, one of which is Nigeria. One of the failures was caused by a program that did not focus directly on poverty and political stability and unstable policies [3]. Even with the expenditure poverty criteria of US $\$ 1$ per capita per day, the number of people living below the poverty line increased from $54.7 \%$ in 2004 to $60.9 \%$ in 2010 [4].

The issue of poverty is still a fundamental problem and is multidimensional in development in Indonesia. Being a fundamental problem because poverty is a problem faced by almost all regions in Indonesia both in urban and rural areas and is very difficult to solve. Whereas multidimensional nature can be seen from two sides, namely the cause and the alleviation side.In terms of causes, poverty is caused by a formulated is to encourage poor families to get out of poverty with the main actors being poor families themselves by always getting attention from the central government, regional government, private sector and universities in the form of coordination and integration. The main strategy that must be done is to empower the abilities, talents and skills of poor families and reduce all the limitations that exist in these poor families. The basic need approach for some poor people still needs to be done.

Keywords: Model Acceleration, Strategy Acceleration, Poverty Alleviation.

variety of backgrounds, while poverty alleviation must also be multidimensional.

In various literatures, many have been offered and have even been implemented in many countries regarding the model and strategy as well as the government's approach to poverty reductionincluding the basic need approach, the employment orientation approach, and through economic growth strategies (economic growth strategy), but all of that has not fully been able to realize one of the great ideals in nation building which is free from poverty. In Indonesia itself, apart from this approach, efforts have been made to reduce poverty through direct and indirect or empowerment programs. Various farming business loans (KUT), people's business credit (KUR), cash direct assistance (BLT), Raskin, underdeveloped village Inpres, Home Surgery then empowerment through PNPM and many other programs.

Judging from the political will that exists, what the government has done in alleviating poverty is sufficient. Especially if the political will is measured by the disbursement of funds issued by the APBN [5]. Similar conditions also occur in regions including in Jambi Province, where the tendency for numbers and poverty levels tends to increase over the past 5 years.

With various models and strategies and approaches that have been taken, the problem of poverty is still a development problem that has not been resolved so far. Thus another model and strategy is needed which is more appropriate in alleviating poverty, especially in the Jambi Province Rural Area. 


\section{LITERATURE REVIEW}

Poverty is often seen as an inability to pay minimal living costs, although some experts argue that poverty is also a lack of access to services such as education, health, information, and lack of public access to development and political participation. The definition of poverty can also be viewed in terms of relative and absolute sides [6]. Relative Poverty Relative poverty is a poor condition because of the influence of development policies that have not been able to reach all levels of society, causing inequality in income distribution. Minimum standards are prepared based on the living conditions of a country at a certain time.

Absolute Poverty Absolute poverty is determined based on the inability to meet minimum basic needs such as food, clothing, health, housing and education needed to be able to live and work. Indonesia uses an absolute definition of poverty that is able to compare poverty in general and assess the effects of inter-time poverty reduction policies.

World Bank (2000) as quoted by Jonathan Haughton and Shahidur R. Khander [7] defines poverty as a lack of wellbeing. One approach used is to regard welfare as mastery of goods in general, so that people can be much better if they have greater resources. The main focus lies in the fact whether each household or individual has adequate resources to meet their various needs. Specifically, poverty is then measured by comparing the income and consumption of each individual with a set number of standards where they are considered poor if their income or consumption is below that standard.

According to Robert Chambert as quoted by Achmad Fatony [8], the essence of poverty is what is called Depriviation Trap which consists of five disadvantages that surround the lives of poor people, namely: poverty itself, physical weakness, alienation, vulnerability, and, helplesness.

According to Chambers, of the five shortcomings of these shortcomings, the mostneeded attention is vulnerability and powerlessness. Vulnerability can be seen from the inability of poor families to provide something to deal with emergency situations such as the arrival of natural disasters, rising fuel prices or diseases that suddenly afflict families. This vulnerability often leads to poverty rockets or "driving wheels of poverty" which causes poor families to have to sell the most valuable assets for consumption needs so that the family becomes increasingly into the valley of poverty. Helplessness is considered the most significant factor in encouraging the process of poverty or impoverishment, because the process of exploitation is in this line in all its forms. Although the substance of powerlessness often appears in the form of exploitation, namely extortion by a stronger group

Furthermore, World Bank (2008) as quoted by Made Kerta Adhi, I Ketut Ardana and I Made Maduriana [9] distinguishes poverty into three, namely absolute poverty, relative poverty, and cultural poverty. Someone belongs to the absolute poor if the income is below the poverty line, no enough to meet minimum living needs, bothb food, clothing, health, boards and education. While poverty relative poverty is an inner poverty level has to do with an absolute poverty line ratio or the proportion of income distribution (welfare) that is lame or uneven. Oscar Lewis stated, cultural poverty emerged as a result of the values or culture adopted by poor people, namely lazy, easy to give up on fate, lack work ethic and so on. Poverty cultural a domino effect from the shackles of structural poverty sits on society too long, or indirectly shows the link between structural poverty and cultural poverty that makes society apathetic, surrender, and view if something happens is fate In measuring poverty rates, there are several approaches, first the Economic approach Poverty from the economic side is measured through the income approach. Second, Purchasing Power Parity (PPP) approach. The World Bank defines the international poverty line as US \$ 1 and US \$ 2 per day in 1993 as measured by the purchasing power parity approach. Purchasing power parity is defined as a method used to measure how much a currency can buy the same number of goods or services in international measurements because the prices of goods and services in several countries are different. While US $\$ 2$ poverty measurement is intended for countries that are in the category of having middle income, such as East Asia and Latin America. This conversion number is calculated based on the price and quantity in each country collected in a survey which is usually carried out every five years.

Third Multidimensional Poverty Index (Multidimensional Poverty Index - MPI) definition of poverty is growing and not just judged by the monetarists. The United Nation Development Program (UNDP) develops the definition of poverty from various aspects by developing amultidimensional poverty index. The multidimensional poverty index identifies the inability of a person to fulfill their basic needs based on three dimensions, namely health, education, and living standards. These dimensions are further reduced to 10 indicators, namely nutrition, child mortality, school duration, school enrollment rates, cooking fuel, type of toilet, water, electricity, type of floor, and ownership of assets. The multidimensional poverty index calculation can be calculated from micro data sourced from household surveys. The MPI methodology can be modified to produce a multidimensional national poverty measure that reflects culture, economy, climate, and other local factors. International MPI is designed as an analytical tool to compare acute poverty between countries.

The results of Mahmood Messkoub's [10] study in Mena Arab countries (Arab and North Africa), found that economic growth and job creation were not good enough in reducing poverty in MENA Arab countries mainly due to the low growth rate of employment opportunities, due to the low skill possessed by workers. Poverty in Nigeria is a long-term problem. Judging from the incidence and dimensions of poverty, there has been an increase in poverty in urban areas from $17.2 \%$ in 1980 increased to $58.2 \%$ in 1996, but fellback to $43.2 \%$ in 2004 . On the other hand, rural poverty increased from $28.3 \%$ in 1980, increased $69.3 \%$ in 1996 and decreased slightly in 2004 to $63.3 \%$. economic growth does not help much to reduce poverty. From the education dimension it shows that poverty is concentrated in the community with basic education [11]. More than $90 \%$ of the poor in Rwanda live in rural areas, most of the income sources of poor households come from wages working in the agricultural sector. As many as $91 \%$ of poor households are below the poverty line. Poor households that depend on a combination of working in the agricultural sector and as a laborer not more than $82 \%$ [12] 


\section{RESEARCH METHODS}

\begin{tabular}{|c|c|c|c|}
\hline $\begin{array}{l}\text { 1. Determination of topics, } \\
\text { research schedules and } \\
\text { studies of the substance of } \\
\text { research }\end{array}$ & $\begin{array}{l}\text { 3. Presurvey and } \\
\text { collection } \\
\text { data in the field } \\
\text { and literature }\end{array}$ & $\begin{array}{l}\text { 5. Seminar and } \\
\text { discussion of } \\
\text { research results }\end{array}$ & 7. Models and \\
\hline & & & $\begin{array}{c}\text { Accelerating Rural } \\
\text { Poverty Eradication } \\
\text { in Provinces } \\
\text { Jambi }\end{array}$ \\
\hline $\begin{array}{l}\text { 2. Discussion of research } \\
\text { instruments and methods } \\
\text { and analysis tools }\end{array}$ & $\begin{array}{l}\text { 4. Processing and } \\
\text { analysis of data }\end{array}$ & $\begin{array}{l}6 . \text { Improvement of } \\
\text { research reports and } \\
\text { print reports }\end{array}$ & \\
\hline
\end{tabular}

\subsection{Overview Poverty in Jambi}

In general, the number of poor people in Jambi Province and in the municipal districts in Jambi Province in the last decade (2010-2017) tended to fluctuate, with the highest number of poor people being in 2015 with a total population of 300,710 people. According to regencies/cities, the highest number of poor people in 2010 was in Jambi City, namely 52.6 thousand people, West Tanjung Jabung Regency 31 thousand people and Merangin District 27.3 thousand people. Whereas in 2017 the highest number of poor people was found in Jambi City, namely 52.08 thousand people, West Tanjung Jabung Regency 36.33 thousand people and Merangin District 35.48 thousand people. Most of the regencies in the province have a poor population in 2017 compared to 2010, only Kerinci Regency, Sungai Penuh City and Jambi City have experienced a decline, although not much.

Similar to the number of poor people, the majority of districts in Jambi Province, the percentage of poor people tends to increase in 2017 compared to 2010. The districts are Merangin, Batang Hari, Tanjung Jabung Timur, Tanjung Jabung Barat, Bungo and Tebo. Based on the results of the study, an interesting thing that can be studied is that in 2011 was a good period where the percentage of poor people both in Jambi Province and district / city decreased, in 2012 the percentage of poor people in Jambi Province and regencies/cities experienced an increase. In other words, 2012 was a turning point in the decline in development achievements in poverty alleviation. This condition occurs more due to the decline in people's purchasing power caused by the decline in prices of plantation and agricultural commodities.

Aside from the number and level of poverty, the other problem picture of poverty is the depth of poverty (Poverty Gap Index) that is one of the indicators used to measure the level or average expenditure gap that occurs in each population, with a measurement standard limited by the poverty line. Districts with more than one poverty depth index during the period 2010-2017 are Sarolangun District, Tanjung Jabung Timur, Tanjung Jabung Barat and Batang Hari. When associated with poverty levels, districts with high levels of poverty have a greater poverty depth index compared to districts /cities with low poverty rates.

The problem of poverty lies not only in the number and percentage of the poor, but also the problem of poverty severity (Poverty Severity Index). The poverty severity index is an index that provides information about the description of the distribution of spending among the poor. The higher the

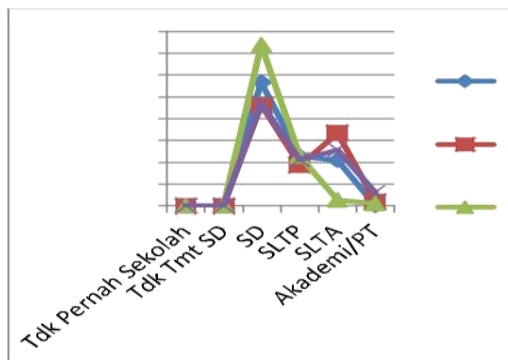

index value, the higher the inequality of expenditure among the poor.

The poverty severity index in the district /city of Jambi Province in 2010 was all less than 0.5. Sungai Penuh City and Merangin Regency have the smallest poverty severity indexes of 0.11 and 0.13 respectively, while the largest are Tanjung Jabung Barat (0.67) and Jambi City (0.49). While for 2017 the smallest poverty severity index was Sungai Penuh City and Muaro Jambi respectively 0.03 and 0.07 , while the largest were Tanjung Jabung Timur District (1.05) and Sarolangun District (0.69).

\subsection{Characteristics of Households Poor}

1. Age

The influence of this age can be attributed to experience and maturity of thinking and acting in dealing with every problem and problem in family life and in society in general. Based on the results of the study, the description of the age distribution of respondents can be described that the highest number of poor household heads is at the age of $35-44$ years, which is equal to 26.70 .

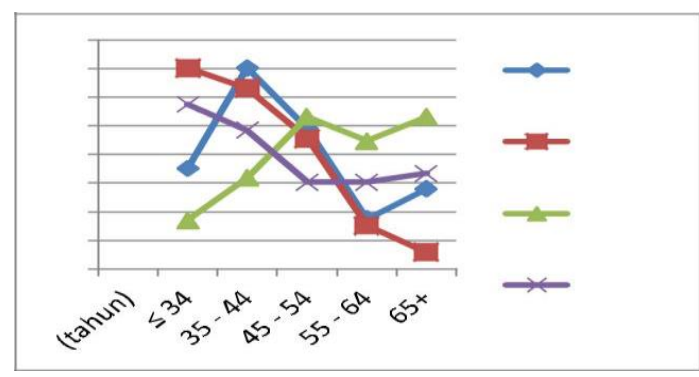

Figure 1: Age Distribution of Poor Rural Household Heads in Jambi Province in 2018.

2. Education 
Education plays a very important role in shaping one's mindset and pattern of action. The higher a person's education, the better the pattern and pattern of the pattern, including its ability to analyze an issue. In the context of poverty alleviation, education is considered a breaker in the poverty chain. It can be informed that most of the education levels of poor household heads of respondents are elementary schools (East Jabung Tanjaung, Tanjung Jabung Barat and Batang Hari) and SLTP (Sarolangun District).

According to the Regency, Tanjung Jabung Timur Regency has the highest number of elementary school graduates $(56.60 \%)$, junior high school $(22.64 \%)$ and senior high school $(20.75 \%)$ and there is no academy or university education. Tanjung Jabung Barat Regency has the highest number of elementary school graduates (46.19\%), senior high school $(33.30 \%)$, junior high school $(18.71 \%)$ and academics or tertiary education with $1.75 \%$. Batang Hari Regency has elementary $(73.86 \%)$, junior high school (22.72\%) and highschool $(2.72 \%)$ and academy or tertiary education with $1.14 \%$. Whereas in Sarolangun District, therewere elementary school education $(46.96 \%)$, highschool $(25.75 \%)$ and junior high school (21.21\%) and Academy or Higher Education as much as $6.06 \%$. In general, the education level of the heads of poor households is of low primary and secondary education. The details are East Tanjung Jabung District 79.24\%, Tanjung Jabung Barat $64.90 \%$, Batang hari $95.52 \%$ and Sarolangun $68.11 \%$.

Figure 2: Distribution of the Education Level of Poor Rural Household Families in Jambi Province in 2018.

\section{Work and Working Hours}

In general, poor families depend their lives mainly on the primary sector namely agriculture, plantations and fisheries or forestry compared to other sectors . S ost respondents living in the field of business sector and the primary sector, especially agriculture and fisheries. Viewed by regency, Tanjung Jabung Timur Regency is the main occupation of poor families dominant in the agricultural sector $(56.14 \%)$ and fisheries (19.29\%), West Tanjung Jabung Regency in the fisheries sector $(52.40 \%)$ and trade $(21.68 \%)$. Batang Hari Regency in the agricultural sector $(31.82 \%)$ and fisheries (30.68\%). Then Sarolangun District $54.54 \%$ worked in the agricultural sector, trade $(13.65 \%)$ and processing industries, especially CPO and Rubber processing (13.65\%)

Based on information as obtained by almost no poor people who have side jobs. Thus it can be concluded that the lives of poor households rely on the main work or main work of agriculture, fisheries and trade (trade with very little capital). Judging from $\mathrm{j}$ am workweek heads of poor households in the province of Jambi between 14 to more than 55 hours per week. Referring to the BPS (National Statistics Agency) criteria as stated earlier, it can be concluded that Sarolangun and Tanjung Jabung Barat Regencies working hours of family heads 35 hours and above (full working) reached $77.26 \%$ and $81.86 \%$ respectively. Whereas Tanjung Jabung Timur and Batang Hari districts with working hours of family heads 35 hours and above are $63.28 \%$ and $30.67 \%$ respectively. The head of the household included in the usual underemployment category (workinghours 14-34 hours) is mostly in Batang Hari Regency (64.77\%) and Tanjung Jabung Timur (32.14\%) while belonging to the category of critical unemployment only in Batang Hari Regency and Tanjung Jabung Timur $4.54 \%$ and $3.57 \%$ respectively. The relative number of poor household heads working normally (working above 35 hours per week), but still in the poor category indicates:

1. Not always long working hours can create/ generate more income.

2. The heads of poor households generally work in the traditional agricultural, plantation and fisheries sectors

3. The head of a poor household works more on relying on the power of his strength rather than skill or skill.

4. With long working hours, even with low income, poor families can survive.

\section{Structure and Education of Household Members}

The results of the study showed that the structure of family members of poor households in the Rural Province of Jambi was generally the core family. There are only $1.28 \%$ in the West Tanjung Jabung Regency and $0.33 \%$ in the Batang Hari Regency in the broad sense. This condition is very reasonable, considering that poor families have limitations, making it difficult for them to invite or accommodate other people to live with them.

Viewed from the burden of dependents, one family head has a burden of between two and three people and three to four people. Tanjung Jabung Timur and Batang Hari Regencies have a burden of 2-3 people per family and Tanjung Jabung Barat Regency and Sarolangun have a burden of 3-4 people.

In general, the education level of the family members of poor households in each district is relatively different. In Batang Hari Regency it is more concentrated in elementary school (52.84\%) and junior high school graduates (26.42\%), in Tanjung Jabung Barat and Tanjung Jabung Timur Regencies concentrated in senior secondary education with $45.93 \%$ and $49.03 \%$ respectively. One more interesting thing happened in Sarolangun District, where $34.81 \%$ of poor family members were educated in Higher Education and $33.03 \%$ had high school education. This illustrates that the fighting capacity of poor families to get out of poverty through education is very high compared to other districts.

\section{Residence}

Judging from the status of home ownership, most of the respondents live in their own homes between $69.0 \%$ and 95.45\%. Tanjung Jabung Timur Regency, the majority of poor families occupy their own homes $(73.80 \%)$ and parents' (22.61\%).While in Tanjung Jabung Barat Regency owned by themselves (69.0\%) and rent (19.88\%), Batang Hari Regency belongs to itself $(95.45 \%)$ and belongs to parents $(4.54 \%)$. Sarolangun Regency occupies the most part of the house itself $(87.87 \%)$, owned by parents and each rent is $6.06 \%$. The data shows that there is still a need for assistance policies for the construction of poor family homes in all sample regions, especially in the East Tanjung Jabung and Tanjung Jabung Barat Regencies. These considerations are due to the relatively large number of poor families who do not have their own homes.

\section{Source of Information}

The main source of information for rural poor households in Jambi Province is PLN (State Electricity Company) with the number of households between $94.74 \%$ and $100 \%$. According to the regency, the main source of information for poor family households in each district other than East Tanjung Jabung Regency is PLN (State Electricity Company) which reaches 
$100 \%$. Especially for East Tanjung Jabung Regency there are still $5.26 \%$ of poor families using Kerosene Lamps.

\section{Source of Clean Water}

The source of clean water used by poor households is mostly dug wells or Drill wells with up to $59.09 \%$ to $99.41 \%$ of poor sample households. Source of clean water comes from dug wells or bore wells in Tanjung Jabung Barat District (99.41\%), The most of rivers in Tanjung Jabung Timur (22.61\%), Most Rainwater in East Tanjung Jabung $(5.95 \%)$ and most PDAMs (drinking water company) in Sarolangun Regency (49.90\%).

\section{Income and Assets}

In general, the monthly income of the heads of poor households is between Rp.500,000 and Rp.2,000,000. Only $7.92 \%$ up to $18.18 \%$ of the income of the household heads of poor households is less than Rp.500,000 and $10.0 \%$ to $13.63 \%$ of the income of the heads of poor households is more than Rp.2,000,000.

\section{Household expenditure patterns}

Theoretically expenditure follows income, meaning that the greater one's income, the greater the expenditure. On the other hand, the smaller the income of a person or family, the greater the share of income that is used for food or food expenditure. Viewed from the distribution of expenditure of poor households, most of them are concentrated in food expenditure between $83.00 \%$ and $95.65 \%$, while non-food expenditure is between $4.34 \%$ to $17.00 \%$. This proves that the largest expenditure of poor families is concentrated in food expenditure and at the same time records the low capacity of poor families to finance non-food expenditure.

\section{Asset ownership}

The inability of poor families to have assets, especially productive assets, is allegedly one of the causes of the poverty of a household from an economic perspective. The absence or lack of ownership of productive assets makes it difficult for poor families to get out of poverty. The results showed that of the 391 respondents, poor households that had assets were $69.00 \%$ to $95.45 \%$. According to the districts of poor households that have the most assets in Batang Hari Regency (95.45\%), then Sarolangun District (87.87\%), Tanjung Jabung Timur (73.80\%) and Tanjung Jabung Barat District (69.00\%).

\section{Health and Medical Complaints}

There is a positive correlation between the level of income and the degree of public health, the higher the income of a family the higher the degree of health, and vice versa. Poor families are usually very vulnerable to health problems. Based on the results of the study, generally complaints about the health of rural poor households in Jambi Province are cough, heat and colds, especially in Batang Hari and Tanjung Jabung Barat Regencies. The main health complaints of poor households in Tanjung Jabung Timur and Tanjung Jabung
Barat Districts, Batang Hari and Sarolangun are Batuk (cough) and Demam (faver).

Meanwhile, when viewed from facilities or facilities for treatment of families of poor households in rural areas, Jambi Province is generally treated at Puskesmas (public Health centers) with respondents reaching $61.81 \%$ to $93.18 \%$. According to the regency, the highest number of treatment for families of poor households in East Tanjung Jabung Regency is Puskesmas $(61.81 \%)$, health and traditional labor practices respectively 7.27. In Tanjung Jabung Barat District, there are Puskesmas (68.23\%), doctor practices (12.35\%), health personnel practices $(8.23 \%)$ and hospitals (5.88\%). Furthermore, the Batang Hari District Health Center was 93.18\% and the hospital was $4.54 \%$. Then Sarolangun District has $64.51 \%$ Puskesmas, $16.12 \%$ doctors and hospitals practice $6.45 \%$.

\subsection{Strategy and Model for Accelerating Poverty Reduction}

Based on information obtained from respondents, poverty in Rural Jambi Province caused by: (1) Lack of capital, (2) Lack of capital to buy fertilizer, (3) Lack of business fields, (4) Low education, (5) Lack of knowledge, (6) Lack of information, (7) HR is unable to compete, (8) Lack of skill, (9) Age factor, (10) Lack of knowledge about entrepreneurship, (11) Lazy to work, (12) Descent, (13) Lack of government assistance and attention, (14) Non-permanent income, (15) Rubber prices continue to decline, (16) Lack of public transportation customers, (17) Low purchasing power, (18) High prices of basic goods while low income and (19) Small business opportunity

Based on the previous problems, which are the main causes of poverty in the Jambi Province, the strategy that can be done is to find a solution from the source of the problem. In other words the model that can be done is based on or based on the self of the poor himself. All respondents are eager to get out of poverty, meaning that there has been an encouragement from within themselves to change their destiny.

Job creation, capital assistance, improvement of poor family education, improvement of knowledge and skills through training, guidance, vocational training centers so that their human resources can increase and have competitiveness, provide access to and information services as wide as possible both employment opportunities, assistance government, training and others, developing entrepreneurial capabilities, encouraging work culture, increasing people's purchasing power, and enforcing inflation. Some of the efforts expected by poor households to get out of poverty are through business:
Tanjung Timur Regency
West Tanjab Regency

\section{Batanghari
Regency}

Sarolangun Regency 


1. Trade
2. Business credit
3. Online business
4. Area nut business
5. Raising native chickens
6. Raising chickens
7. Open a grocery store
8. Farming
9. Open a cafe business
10. Open a breakfast business
11. Raising catfish
12. Trade results own fish catch
13. Fishing business
14. Fish cultivation
15. Recycle items and sell them
16. Make shrimp crackers
17. Open a restaurant
18. Trade fish

1. Trade

5. Raising native chickens

8. Farming

9. Open a cafe business

10. Open a breakfast busines

1. Raising catfis

13. Fishing business

14. Fish cultivation

16. Make shrimp crackers

18. Trade fish
1. Trade

2. Trade fish

3. Fish container

4. Fish processing business

5. Opening a UMKM business

6. Candied business

7. Has pompong and fishing gear

8. Cracking business

9. Food shop business

10. Tailor

11. Business for washing cars and motorbikes

12. Areca shop

13. Buying and coconuts

1. Food shop
business
2. Enterprises
sewing
3. Open
selling kiosk
4. Fish cages
5. Gardening
6. farming
7. Open
chicken farm
8. Trade

1. Food

shop 1 1. Trade

2. Open a restaurant

3. Open a shop

4. Raising S fire

a 5. Raising goats

6. Raising chickens

7. Raising quails

8. Fruit gardening

9. Selling on the market

a 10. Open a workshop business

11. Open chili land

12. Wood furniture business

13. Open your own rubber land

14. Open your own palm land

15. Continuing the bamboo Business

\section{CONCLUSION AND SUGGESTION}

\subsection{Conclusion}

1. Most districts in Jambi Province, the percentage and number of poor people tend to increase in 2017 compared to 2010 .

2. The model of accelerating rural poverty alleviation in Jambi Province which can be formulated is to encourage poor families to get out of poverty with the main actors being poor families themselves by always getting attention from the central government, regional government, private sector and universities in the form of coordination and integration.

3. The main strategy that must be done is to empower the abilities, talents and skills of poor families and reduce all the limitations that exist in these poor families.

\subsection{Suggestion}

1. The basic need approach for some poor people still needs to be done

2. Job creation, improvement of skills and knowledge and opening access to and information as widely as possible for poor families in various aspects becomes very important.

3. The poverty alleviation base is the poor and makes it a subject.

\section{Aknowledgement}

The authors would like to thank the Ministry of Research, Technology and Higher Education of the Republic of Indonesia for supporting this research funding.

\section{References}

[1, 11] Ben E. Aigbokhan, (2008). Growth, Inequality and Poverty in Nigeria. ACGS/MPAMS Discussion Paper No.3. Prepared for United Nations Economic Commission for Africa (UNECA) Addis Ababa, Ethiopia February, 2008. Economic Commission for Africa.

[2] Hyun H. Son and Nanak Kakwani, (2004). Economic Growth and Poverty Reduction: Initial
Conditions Matter United Nations Development Program. Working Paper Number 02 August 2004.

[3] Mike I Obadan. Poverty Reduction in Nigeria: The Way Forward. CBN Economic review Volume 39 No. 4.

[4] Okoroafor, Michael Onyedikachi and Nwaeze Chinweoke, (2013). Poverty And Economic Growth In Nigeria 1990-2011. The Macrotheme Review 2 (6), SI-IMT, 2013.

[5] Sukidjo and Ali Muhson, (2010). Model of Empowerment of Poverty Alleviation Based on Local Institutions and Business Development in the Special Province of Yogyakarta. Yogyakarta State University. Yogyakarta

[6] BPS, (2014). National Poverty Profile and Analysis.

[7] Jonathan and Khander Shahidur R, (2012). Guidelines on Poverty and Inequality: Handbookon Poverty and Inequlaity. Salemba Empat. Jakarta

[8] Achmad Fatony, (2011). Poverty Alleviation Policy Based on Participatory Poverty Assessment: The Case of Yogyakarta. Journal of Socioconseptia volume 16 number 02. 2011

[9] Made Kerta Adhi, I Ketut Ardana, I Made Maduriana, (2016). Actors CausingCultural Poverty and Local Wisdom-Based Eradication Models: AStudy of the Poor in the Kintamani Mountains, Bali . Journal of Bali Studies Vol. 06,No. 02, October 2016.

[10] Mahmood Messkoub, (2008). EconomicGrowth, Employment and Poverty in the Middle East andNorth Africa. Workin Paper No. 460.Instituteof Social Studies.

[12] Minestry of Finance and Economic Planning, (2007). The Republic of Rwanda: Economic Development and Poverty Reduction Strategy. 2008-2012. 